\title{
Research on the Allocation of China's National Defense Patent System
}

\author{
Wenqiong Fang, Yangyang Yu
}

PLA Army Service Academy, University City, North 1st Road, Chongqing, China

78828070@qq.com

\begin{abstract}
Keywords: national defense patent system; institutional allocation; institutional coupling;
\end{abstract} institutional vacuum.

\begin{abstract}
This article is a phased outcome of the National Social Science Fund Project "Research on the Innovation of National Defense Patent System Based on the Perspective of Military-Military Integration" (15CFX046). Objective: To provide reference for the allocation of national defense patent system.Methods: Using the relevant theories of institutional allocation in institutional economics, this paper analyzes China's current national defense patent system. Results and conclusion: Only the coupling system between the internal systems of the national defense patent system can eliminate the institutional vacuum and achieve the expected goal of the national defense patent system.
\end{abstract}

\section{Introduction}

With the rapid development of world economic integration and modern science and technology, the competition among science and technology, economy and comprehensive national power among countries in the world is becoming increasingly fierce. However, the establishment of China's national defense patent system is relatively short, and there are certain defects in many aspects of system construction. It is obviously unable to meet the development needs at this stage.This paper uses the relevant theories of institutional allocation in institutional economics to analyze China's current national defense patent system and finds that only the coupling system between the internal systems of the national defense patent system can eliminate the institutional vacuum and truly realize the expected goal of the national defense patent system. At the same time, this paper takes the relatively sound foreign defense patent system as a reference, and based on China's actual national conditions, puts forward several suggestions that are conducive to the development of China's national defense patent system.

\section{Different interpretations of the system}

\subsection{The concept of the system}

Institution, or organizational system, is a concept in social science. From the perspective of the social sciences, institutions generally refer to a social structure that regulates individual actions by rules or modes of operation. These rules contain the value of society, and its operation recognizes the order of a society.The concept of organizational system is widely used in the fields of sociology, political science, and economics.

Marx said: The system is nothing but a product of the interactions that have existed between individuals.

Institutional economics founder Thorstein B Veblen defined the system in 1899 as: "Institutions are essentially the general habits of individuals or societies about certain relationships or certain effects, and the way of life. It constitutes the integration of a system that is prevailing at a certain stage or at a certain stage of social development, so from a psychological point of view, it can be generalized as a popular mental attitude or a popular life. theory."

Douglass C.North, a new institutional economist in the United States, believes that institutions are a "rule that regulates individual behavior."

Although the above definitions have different emphases, they all point out the different aspects 
of the system or different aspects of the system. By organically integrating them, we can see the basic structure of the system and understand the meaning of the system from many aspects.

\subsection{Type of structure of the system}

Institutions are the most basic variables affecting human economic behavior, resource allocation and economic performance. Institutional analysis is the basis of economic analysis. The problem of institutional allocation is an important part of the system research.The purpose of the study system allocation is to coordinate various institutional arrangements and enhance the orderliness of the institutional system to give full play to the functions of the institutional system.However, within the institutional system, the structure between various institutional arrangements is not necessarily reasonable, and the orderliness of the system may be low for various reasons, and even make the institutional system difficult to operate normally.According to the interrelationship between various institutional arrangements within the institutional system, the internal state of the institutional system can be divided into three types: institutional coupling, institutional conflict, and institutional vacuum. The institutional coupling in these three states indicates that the institutional system is coordinated and orderly, and there are organic connections between various institutional arrangements; while the latter two indicate the disorder within the institutional system. The goal of institutional allocation is to achieve institutional coupling, reduce and avoid institutional conflicts and institutional vacuum.

\section{Overview of foreign defense patent system}

The national defense patent system originated from the birthplace of the patent system - the United Kingdom. In the mid-19th century, the British weapons manufacturer Armstrong's two patents on the rifle and the rear rifle were published by France and Germany on the weapon system.This incident triggered the Western countries to think deeply about the impact of patent technology disclosure on national security, and then established a secret patent system, namely the national defense patent system.

With the development of the times and scientific and technological progress, the world's major military powers have paid more attention to the use of a sound national defense patent system to protect the country's core security interests and promote the innovation and development of national defense science and technology. There are generally two types of defense patent systems in countries around the world: systems that do not authorize patent applications and systems that authorize patent applications. The system for not authorizing patent applications is mainly that the relevant state agencies place patent applications involving national security in a confidential state, do not grant patent rights before decryption, and transfer the inventions involved to the defense department, and the state provides the applicant with the patent. Financial compensation. The object of protection of this system is essentially an invention that has not yet been patented.Its main countries are Spain, the Netherlands, Canada and so on.The typical country is France. The system for authorizing patent applications is mainly for the state-related agencies to conduct confidential examinations of patent applications involving national security, and to grant qualified patents but not to publish and announce them, such as the United Kingdom, Australia, South Korea, Brazil, etc. For the United States and Germany.

In general, foreign defense technologies involving confidentiality have a strict and standardized secrecy review system, and there are also many harsh conditions in terms of the use of results.At the same time, some foreign countries have classified the system of confidentiality review, regular declassification and confidentiality, and timely granting reasonable economic compensation to rights holders. The supporting systems are also relatively mature, and the strong intellectual property protection awareness and developed judicial review mechanisms in Britain and the United States also It is conducive to the effectiveness of the national defense patent system, the protection of technological exclusive rights in the field of national defense, and the defense of patent infringement in defense, which have become the driving force for the continuous innovation of national defense technology.It can be seen that the development direction of national defense patent systems is also aimed at eliminating institutional conflicts and institutional vacuum, and strives to 
form a coupling system for national defense patent systems.

\section{Problems in the allocation of China's national defense patent system}

The internal institutional conflicts of the national defense patent system and the existence of the institutional vacuum have greatly reduced the orderly degree of the national defense patent system system, and its essence is the irrational performance of the national defense patent system.There are many reasons for the irrationality of this system. It may be due to the characteristics of bounded rationality inherent in human beings, the inherent conflicts between individual rationality and collective rationality, and the mechanism of institutional change. .

\subsection{Institutional conflicts exist in the system formulation of the national defense patent system}

\subsubsection{Conflict between openness and confidentiality}

The original intention of the establishment of the patent system was to give the inventor a unique technique to use the monopoly power in exchange for the inventors to disclose their technological achievements, thereby promoting the technological progress of the whole society. The national defense patent system is developed on the basis of the ordinary patent system. Therefore, the disclosure of patent technology content is also a basic requirement of the national defense patent system.Promoting the overall technological progress of the defense industry through technology disclosure and establishing modern defense is also the ultimate goal of establishing a national defense patent system.In short, defense patents have an inherent need to disclose technical content.However, because national defense inventions involve national security and national defense interests, the application for defense patents, acceptance of approval, defense patent transfer, fees collection, agency selection, secret level change and decryption, and defense patent information exchange methods must all be Follow the requirements of the National Secrecy Act and the relevant confidentiality regulations. Strict confidentiality requires that defense technology cannot be fully disclosed.At present, the technical disclosure of China's national defense patents is mainly achieved through internal disclosure (the National Defense Patent Office publishes technical abstracts to certain units by issuing internal announcements). Therefore, the external pressure of open internal demand and confidentiality is It has become an institutional conflict that cannot be avoided in the allocation of the national defense patent system.

\subsubsection{Conflict between public and private rights}

As a kind of patent, national defense patents obviously have the general attribute of intellectual property, that is, private rights. The private property of intellectual property has three aspects: First, intellectual property reflects the personality and property interests of the creators of knowledge products, and is a specific specific private right, which belongs to the category of civil rights, that is, has the property of private rights.Secondly, the Agreement on Trade-Related Aspects of Intellectual Property Rights (hereinafter referred to as the "trips agreement" requires all members to "recognize intellectual property rights as private rights". China is a member of the trips agreement, which is binding on China.Legislation in modern countries generally also constructs its intellectual property system from the nature of private rights.Third, the rationality of private property rights of intellectual products stems from the labor value theory in economics.Labor not only creates the value of materialized goods, but also creates the value of knowledge products."People are given property rights from his own intellectual creation. This is a natural human right." The patent law only confirms it, not creates it.

National defense patents refer to invention patents that involve national defense interests and have a potential role in national defense construction and need to be kept secret. For the sake of national defense security, the state must hold these core technologies in their hands to maximize their technological advancement in defense and the construction of weapons and equipment. The important role of national economic construction, and the vast majority of national defense research investment comes from the state's financial allocation. Therefore, national defense patents are undoubtedly public.

From the above analysis, it can be concluded that the national defense patent system has institutional conflicts within the system due to its particularity. This kind of institutional conflict is 
related to the characteristics of the national defense patent itself, so it cannot be avoided. If it cannot be eliminated, it can not Bringing the advantages of the national defense patent system to encourage competition and protect innovation will create a series of problems that will seriously hinder the progress of China's national defense science and technology.

\subsection{The institutional vacuum of the national defense patent system has an institutional vacuum}

\subsubsection{Lack of incentive structure}

First, China's secrecy work on national defense patents is mainly based on the Law on the Protection of State Secrets, the Regulations on National Defense Patents, the Regulations on the Secrecy of the People's Liberation Army, the Measures for the Secrecy and Declassification of National Secrets of National Defense Science and Technology Achievements, and National Patents. The fourth notice of the bureau was launched.The confidentiality of national defense patents is a full-scale process, and the relevant confidentiality provisions must be observed throughout the entire process from application, acceptance, review to transfer and implementation.Moreover, compared with ordinary patents, national defense patents have longer confidentiality periods, wider confidentiality scopes, and more cumbersome confidentiality procedures. The creators of national defense scientific and technological achievements do not match the benefits they deserve, and they have cracked down on their applications to some extent. The enthusiasm of national defense patents.

Second, many of China's national defense science and technology achievements belong to the country. For example, in the issue of intellectual property rights in the national defense science and technology industry, the single-property model of "national ownership" has been emphasized. The "Interim Measures for the Development of Weapons and Equipment Contracts" clearly stipulates the development of weapons and equipment. The technical achievements are owned by the state. The stipulation of such rights vests makes the R\&D units or individuals of national defense patents no longer care about the fate of the scientific research results after obtaining partial compensation, because they no longer enjoy any rights to them.

Third, the national defense patent army has more difficulties in transferring people.Article 6 of the National Defense Patent Regulations clearly stipulates that "in the period of protection of national defense patent rights, the National Defense Patent Office has the right to make timely decryption decisions because the situation does not need to remain confidential."At the same time, the specific procedures for the decryption of national defense patents are clearly stipulated for the patentee to request decryption, the decision of the National Defense Patent Office, the publication of the National Defense Patent Circular, and the report to the Chinese Patent Office. Finally, the national defense patent is converted into an ordinary patent.Among them, if the patentee belongs to the unit of ownership of the whole people, it also needs to attach a copy of the document that originally determined the opinion of the secret level authority. The process of transferring the national defense patent army to the people is extremely cumbersome.

\subsubsection{The legal system is not perfect.}

Douglass C.North has said that almost any system is better than no system. Therefore, in the absence of a formal system, the informal system will fill this "vacuum."The existence of the institutional vacuum makes some individuals in the pursuit of their own interests, while harming the interests of others or the society as a whole without being punished, thus actually encouraging such behaviors, making it difficult for people's behavior to be effectively restrained and regulated. It brings harm to the development of social economy.China has not yet established a complete national defense patent system and supporting system. Therefore, various informal regulations, such as laws and regulations concerning the defense and decryption of national defense patents, national defense patent incentive compensation, national defense patent judicial relief, and national defense patents transfer to the people, Become a substitute for filling the vacuum of the defense patent system.As a useful supplement to the national defense patent system, these rules and regulations are of more significance for China's modern defense construction.

In addition, in addition to the "National Defense Patent Regulations", laws and regulations concerning defense patents are departmental regulations or administrative regulations, lacking 
specific laws at the common law level, generally lower legal levels, and insufficient authority and effectiveness of the system.Moreover, the relevant provisions of national defense patents are scattered in various laws or departments and regulations, and cannot cover all aspects of the national defense patent system. Therefore, China still needs a systematic and perfect national defense patent law.

\section{Countermeasures for Promoting the Realization of the Target of National Defense Patent System}

\subsection{Improve the confidentiality and decryption system}

In order to protect national security and protect national defense interests from infringement, countries that implement confidential patents attach great importance to the formulation and improvement of laws and regulations related to confidential patents.In addition to the provisions of the National Security Law or the National Secrecy Act, some countries also have separate secrecy patent regulations, such as Denmark; some countries place the content of secrecy patents in patent laws, such as the United States, Germany, etc. The country has added a chapter in its patent law "protection of confidential inventions" to increase the emphasis on confidential patents, such as Russia; and some countries, through the Intellectual Property Code, to protect applications for confidential patent inventions, such as France.In addition, the countries that implement the secrecy patent system also stipulate a complete management system in the law. Some countries not only have special procedures and institutions to review patent applications that require confidentiality, but also set up special agencies to manage state-owned secret patents. .

On the basis of learning from the foreign secret decryption system, we need to determine the scientific secret decryption basis, further clarify the national defense patent secret decryption standard, implement classified management of different types of national defense patents, and separately establish conditions, standards and procedures for confidentiality and decryption. Implement the rules and improve the confidentiality and confidentiality decryption system.It is also possible to use some cities with developed military and civilian integration in China as a pilot, and regularly review the national defense patents of military research institutes and military enterprises within the scope of the pilot, and review the confidentiality of patents and re-determine the confidentiality level for early detection. Definable defense patent technology.

\subsection{Establish and improve the incentive compensation system}

The applicants and developers of China's national defense patents are mainly research institutes, colleges and universities, etc. Therefore, while considering national interests, it is also necessary to consider how to fully mobilize the enthusiasm of national defense patent R\&D units to participate in national defense scientific research projects.At the same time, the confidentiality of national defense patents restricts the promotion and implementation of patent-applicant technologies in the civilian sector, which has caused economic losses to patent applicants to a certain extent. Therefore, reasonable compensation should be given to patent applicants or patent holders.

The main problems in China's current national defense patent compensation are insufficient compensation and incomplete compensation, not timely, strengthening the compensation and strength of defense patents, giving applicants no compensation for loss of patent rights, or holding positions in the national defense field. The invention patents belong to the unit and are beneficial to encourage these units and researchers to actively participate in national defense scientific research projects and promote the production of scientific and technological innovations.Specifically, the compensation system for national defense patents can be specified in more detail in the improvement and adjustment of laws and regulations; the specific provisions on the assessment and issuance of compensation fees can be refined to improve their operability; if the national defense patentee compensates When dissatisfied, there are perfect administrative and judicial relief procedures to provide protection. 


\subsection{Establish a national defense patent system with clear property rights}

Only by clarifying the ownership of national defense patent rights will it be conducive to the improvement and development of the national defense patent system, in order to achieve a balance between national security interests and national defense patent rights.Therefore, in the "Defense Law", it should be clear whether the national defense intellectual property rights belong to national defense assets, and specify who will own and exercise the national defense assets.According to the basic theory of the patent law, for most defense patents applied by private enterprises and individuals, it should be determined that the enterprise and the individual are owners, but they are supervised by the defense patent administration department.In the Patent Law, the ownership of national defense patents by individuals and non-state-owned units is clarified.For defense science and technology completed by cooperation between defense units and private units, between defense units, between defense enterprises and foreign enterprises, special issues must be made for the attribution, sharing, and exercise of patent application rights.

\subsection{Improve the system}

The institutional structure is a complex institutional system that is coupled by a large number of institutional arrangements. There are always various inter-dependencies and correlations between institutional arrangements. This means that the efficiency of institutional structures is not simply equal to the individual systems. The sum of efficiency. We should, as soon as possible, revise and improve the "National Defense Patent Regulations" and formulate implementation rules in light of actual needs, and try to formulate a special national defense patent law. While gradually improving other national defense patent-related policies and regulations, we must further establish and standardize national defense. Patent management agency.In the end, it will form a national defense patent system with Chinese characteristics, which is standardized and standardized, with efficient and smooth approval, efficient transformation of results, and incentive and protection measures.

In summary, although the work of China's national defense patent system has maintained sustained development, due to the short period of establishment of the national defense patent system, there are various institutional conflicts and institutional vacuums within the national defense patent system. It is also necessary to continuously develop and improve the development of the times. Constantly put forward new requirements for the national defense patent system, we must find new problems in sustainable development, solve new problems, and finally form the internal institutional coupling of the national defense patent system, the system system is standardized, the examination and approval is efficient and smooth, the results are highly efficient, the incentive mechanism and The national defense patent system with Chinese characteristics is not only conducive to safeguarding national interests and national defense security, but also conducive to the development of military-civilian integration development strategy and national scientific development, and is also conducive to strengthening the country's comprehensive strength.

\section{References}

[1] Ostrom, Elinor. Governing the Development: The Evolution of Institutions for Collective Action. Cambrige: Cambrige University Press, 1990.

[2] Douglass C.North. Institutions, Institutional Change and Economic Performance. Cambrige: Cambrige University Press, 1990.

[3] Granovetter, M. Economic-action and social-structure - the problem of embeddedness. American Journal of Sociology. 1985(3):481-510.

[4] Grief, Avner. Cultural Beliefs and the Organization of Society: Hidtorical and Theoretical Reflection on Collectivist and Individualist Societies. Journal of Political Economy 1994(5): 912-950.

[5] Ruth L Gana. The Myth of Development, The Progress of Rights: Human Rights to Intellectual Property and Development. Law \& Policy, 1996, 318-20. 
[6] DCio. Department of Defense Instruction 3201. 01: Management of DOD Research and Development Laboratories. Washington: United States Department of Defense, 2006. 